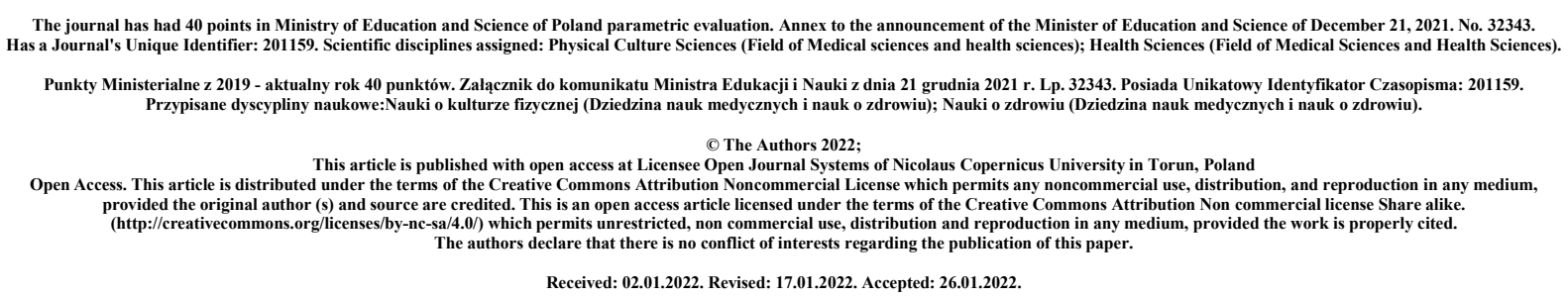

\title{
The knowledge of parents about frequency of body posture defects in early school age children
}

\author{
Dr. Anna Makarczuk \\ University of Lodz, Faculty of Educational Sciences, \\ The Education Center for Sport Pedagogists, \\ mail: anna.makarczuk@now.uni.lodz.pl \\ ORCID: 0000-0001-8668-0737
}

Key words: posture defects, early school education, parents' knowledge

\section{Summary}

The aim of the research was an attempt to assess the level of knowledge of parents of early school children about the frequency of posture defects. The research was conducted in 2017-2018 in five primary schools in Lodz. The method of diagnostic survey and analysis of documents were used. The study involved 521 parents of both genders. Data from 257 health cards were analyzed. The analysis of the obtained results indicates a low (unsatisfactory) level of parents' knowledge of the occurrence of posture defects in children.

\section{Introduction}

Body posture defects pose a significant threat to the proper functioning of the human body. The deviations in body posture, characteristic for individual moments of ontogenesis, can easily turn into permanent deformations. Early diagnosis and compensation of the resulting disorders is the best way to work against posture deviations, which in the later period significantly reduces the occurrence of serious changes, i.e. posture defects ${ }^{1}$.

Unfortunately, parents and guardians are often unaware of the nature of the threat, and thus also of the therapeutic possibilities in a specific case. Selected physical activity does not always have a positive effect on the child's body posture. A common misconception is that every move is good for your health. On the other hand, a sedentary lifestyle is certainly a destructive factor in the locomotor system - especially in the early stages of ontogenesis ${ }^{2}$. A parent's awareness of a possible posture defect in a child is a key element in the process of preventing and compensating for disorders. Only constant care for body posture and, if necessary, quick therapeutic intervention give a chance to maintain health and physical fitness in the perspective of the whole human life.

\footnotetext{
${ }^{1}$ Kutzner - Kozińska M. Proces korygowania wad postawy. Wyd. AWF Warszawa; 2001. 32. Polish.

${ }^{2}$ Kasperczyk T. Wady postawy ciała. Wyd. Kasper. Kraków; 1996. 5 - 7. Polish.
} 


\section{Material and method}

The aim of the study was an attempt to assess the level of knowledge of parents of early school children about the incidence of posture defects and deviations. For the purposes of this study, the following research questions were formulated:

- The main problem

1. What is the level of knowledge of the surveyed parents about the frequency of defects and postural deviations of their children?

- Specific problems

2. What is the frequency of postural defects in children of the surveyed parents, in their opinion?

3. Is there a large discrepancy between the opinion of the surveyed parents and the results of the analysis of orthopedic examination cards in terms of the incidence of posture defects?

4. What are the most common posture defects among the children of the surveyed parents?

The research was carried out in 2017 and 2018 in the city of Łódź. The method of diagnostic survey and analysis of documents were applied. The questionnaires were filled in by parents of children from primary schools (grades 1-3) from various districts of Łódź: Śódmieście (Primary School 111), Łódź Górna (Primary School 29), Widzew (Primary School 34), Polesie (Primary School 44) and Bałuty (Primary School 55). A total of 521 correctly completed questionnaires were obtained. The analysis of children's health records allowed for obtaining information on the occurrence of posture defects in 257 children, although for various reasons (no current health records, no access), these data are unfortunately not complete.

The original questionnaire of the survey contained 25 questions, most of them closed ones. The questions concerned various aspects related to the occurrence of posture defects in children, e.g. diagnosis, corrective procedure, general recommendations and health contraindications.

To be objective, the assessment of the frequency of occurrence of posture defects cannot, of course, be carried out based on the opinion of the parents. In this case, however, it was about assessing the level of parents' knowledge of body posture defects and an attempt to compare the actual state (resulting from medical examinations) with the opinion of the respondents.

\section{Results}

The analysis of the collected research material was carried out in relation to the research problems posed in the study.

The most frequent deviations from the correct posture in the children of the examined parents are disturbances in the feet - mainly longitudinal flat feet (Table 1). Parents declared the presence of this defect in $7.3 \%$ of cases. The second most frequently indicated disorder is lateral curvature of the spine (scoliosis) - 5.8\%. Knee valgus was ranked third $-3.6 \%$, and heel valgus was ranked fourth $-2.3 \%$. 
Tab 1. The occurrence of body posture defects and deviations in the opinion of the surveyed parents

\begin{tabular}{|l|c|c|}
\hline Type of defect/ deviation & {$[\mathbf{N}]$} & {$[\%]$} \\
\hline Shoulder asymmetry & 2 & 0,4 \\
\hline Scapular winging & 3 & 0,6 \\
\hline Valgus knees & 19 & 3,6 \\
\hline Valgus heels & 12 & 2,3 \\
\hline Flat feet & 38 & 7,3 \\
\hline Scoliosis & 30 & 5,8 \\
\hline
\end{tabular}

There is a huge difference between the declared frequency of individual posture defects and the actual state of affairs, resulting from the data obtained after orthopedic examinations ( $\mathrm{Tab} 2$ ). Unfortunately, this comparison cannot be complete, because it was not possible to complete all the medical records of the children of the surveyed parents. Nevertheless, the differences, even in this smaller sample, are significant. This fact proves the parents' low awareness of the occurrence of a posture defect in their child.

Tab 2. The frequency and type of posture defects and deviations in children (medical examinations)

\begin{tabular}{|l|c|c|}
\hline Type of defect/ deviation & {$[\mathbf{N}]$} & {$[\%]$} \\
\hline Shoulder asymmetry & 149 & 58 \\
\hline Scapular winging & 62 & 24 \\
\hline Valgus knees and heels & 123 & 48 \\
\hline Flat feet & 90 & 35 \\
\hline Scoliosis & 46 & 18 \\
\hline Summary $^{3}$ & $\mathbf{X}$ & $\mathbf{X}$ \\
\hline
\end{tabular}

The most common deviation in body posture in the children of the examined parents turned out to be shoulder asymmetry. The analysis of health records shows that it occurs in as many as $58 \%$ of children (Tab 2) but the researched parents were only slightly aware of this state of affairs. Only $0.4 \%$ of the respondents indicated the occurrence of that deviation in their children (Tab 1). Perhaps, but unlikely, the parents did not consider shoulder asymmetry a serious postural deviation and therefore did not mention it in the studies. And yet it is a very disturbing symptom that may indicate scoliosis of the thoracic spine.

The second most frequent deviation in children's posture is valgus of the heels and knees (48\%). Also in this case, the respondents indicated a relatively low scale of these defects. In the case of knee valgus it was only $3.6 \%$ of indications, and in heel valgus it was $2.3 \%($ Tab 1$)$.

The third most frequent examined occurrence was longitudinal flat feet - 35\% of cases. The surveyed parents indicated them in $7.3 \%$ of children (Tab 1), thus the discrepancy between the actual state of affairs and knowledge about it, seems to be very obvious as well. The study also assessed the position of the blades in the sagittal plane, i.e. their protrusion. According to parents, it occurs in only $0.6 \%$ of children but again the analysis of health records showed that this percentage was $24 \%$ (Tab 2).

\footnotetext{
${ }^{3}$ The $\%$ values do not count towards 100 , because many children had more than one posture abnormality.
} 


\section{Discussion}

The issue of posture defects in children and adolescents has been the subject of numerous reports and articles for several decades. The authors most often deal with the frequency of postural defects in a given population, analyze the causes, try to evaluate various methods and techniques of correcting these disorders, and look for the relationship between the child's lifestyle (level of physical activity) and the state of his motor system, and thus also his, body posture.

According to the NIK report from 2020, posture defects are the most common health disorders (before allergies, overweight and obesity) of children and adolescents at school age. According to various sources, it affects about $50-60 \%$ of students ${ }^{4}$. However, the most worrying fact is that, according to the authors of the report: "Schools do not organize the prevention of posture defects in students in a comprehensive manner. Cooperation with parents in this area is limp. Municipalities are also not aware of the importance of this issue, they do not initiate close cooperation of schools with the health service and families, do not supervise the process of correcting children's attitudes - as a rule, they are not interested in this issue, shifting all responsibility to schools"5.

Maciałczyk - Paprocka conducted the research on the frequency of defects and postural deviations in a large group of children (2,984 people) from primary schools ${ }^{6}$. The author found posture deviations in a significant percentage of children and adolescents $71.4 \%$. The greatest number of deviations was observed in 7-year-old children, the least in 12year-old children. Deviations in body posture were significantly more frequent among boys. In turn, the researcher estimated the frequency of posture defects at the level of $18.4 \%$ of all examined children. The age at which they appeared most often was 10 years of age. They were significantly more frequent in boys $(19.3 \%)$ than in girls $(17.4 \%)$.

More recent data on the incidence of posture defects in school children is provided by a 2020 study conducted by Kochman and Studzińska, in a group of 100 children aged 11-14 . The researchers estimated that postural defects occur in $24 \%$ of respondents. The most common disorders are flat feet (58\%) and lateral curvatures of the spine $(21 \%)$. The authors did not assess the frequency of postural deviations - only defects, i.e. cases of more advanced deviations, most often also complex - hence the relatively low percentage of posture disorders occurrence.

In the present study, defects and postural deviations occurred in $73 \%$ of children. This result is consistent with the results of the Maciałczyk-Paprocka research $(71.4 \%)^{8}$ and the data from the NIK report from $2020(50-60 \%)^{9}$.

As can be seen from the above list, in recent years, high percentages of the incidence of defects and posture deviations are often found in research results. A positive symptom is the relatively low frequency of advanced and complex disorders - posture defects. It is around $20 \%$, which is confirmed by this research as well.

The attempts to assess the state of knowledge and awareness of parents about postural defects, seems to be an independent trendof scientific research.

\footnotetext{
${ }^{4}$ https://www.nik.gov.pl/aktualnosci/profilaktyka-wad-postawy.html (dostęp: 11.01.22r).

${ }^{5}$ Ibidem

${ }^{6}$ Maciałczyk - Paprocka K. Epidemiologia wad postawy u dzieci i młodzieży. UM w Poznaniu; 2013. praca doktorska, www.wbc.poznan.pl; 43, 88 - 89. Polish.

${ }^{7}$ Kochman D, Studzińska A. Analiza częstości występowania oraz czynników wpływających na powstanie wad postawy u dzieci w wieku szkolnym. W: Innowacje w pielęgniarstwie i nauka o żywieniu. 2020; 3(5). 69 - 95.

${ }^{8}$ Maciałczyk - Paprocka K. Epidemiologia wad postawy u dzieci i młodzieży. UM w Poznaniu; 2013. Praca doktorska, www.wbc.poznan.pl; 43, 88 - 89. Polish.

${ }^{9}$ https://www.nik.gov.pl/aktualnosci/profilaktyka-wad-postawy.html (dostęp: 11.01.22r).
} 
In this study, a large discrepancy was found between the incidence of posture defects indicated by the surveyed parents and the actual state - resulting from the analysis of children's health records. It can be said that the parents greatly underestimated the scale of the phenomenon. Their declared estimates of the occurrence of defects do not reflect the real picture in which the occurrence of defects is several dozen times higher - e.g. shoulder asymmetry: $58 \%$ according to medical examinations vs $0.4 \%$ according to parental opinion!

The low level of parents' knowledge about posture defects and their correction is confirmed by the Sitek's study ${ }^{10}$. Almost half of the surveyed parents (48\%) are unable to indicate the area in which the child has a posture defect. The same number of respondents cannot mention any name that would describe a defect of posture. More than $60 \%$ of children with a deviation in body posture do not attend corrective gymnastics classes. These are alarming figures.

The author of this report made similar observations over ten years ago ${ }^{11}$. When examining the awareness and actions of parents of preschool children, she stated that children most often do not perform corrective and compensatory exercises at home (72\%), and they attend corrective gymnastics only once a week (67\%). A significant percentage of people spend five or more hours a day sitting (40\%), most often playing on the computer. The incidence of posture defects was estimated at the level of $70 \%$ of the studied population.

Research conducted in the following years ${ }^{1213}$ showed a slight increase in parents' awareness. However, it is still not a satisfactory level.

Lack of knowledge, often even the lack of awareness of the existing dangers and ways of minimizing them, causes the parents to disregard the problem, often ignoring it and significantly reduce the child's chance of recovering. It is worth to mention that no corrective gymnastics, even the best carried out, will be effective when the child does homework at home in an asymmetrical position of the torso, sits (slouching) a lot at the computer and has no opportunity or motivation to take up physical activity.

\section{Summary and Conclusions}

The analysis of the research results entitle to formulate answers to the research questions posed at the beginning:

1. In the opinion of the surveyed parents, the frequency of occurrence of defects and posture deviations is low and amounts to about $5-8 \%$.

2. There is a significant difference between the data obtained from the medical examination records and the survey results, amounting to a level of several dozen percent.

3 . The most common abnormalities in children's posture are shoulder asymmetry (58\%), knee and heel valgus $(48 \%)$ and flat feet $(35 \%)$.

Referring to the main problem, it should therefore be stated that the level of knowledge of the surveyed parents about the frequency of postural defects in their children is very low.

The effectiveness of preventive and therapeutic measures in the treatment of body statics disorders largely depends on the conditions that we are able to create for a child on a

\footnotetext{
${ }^{10}$ Sitek M. Wady postawy dzieci - stan wiedzy rodziców. Wychowanie Fizyczne i Zdrowotne. $2014 ; 5: 14$ - 17.

${ }^{11}$ Makarczuk A. Świadomość rodziców w zakresie występowania wad postawy ciała wśród dzieci w wieku przedszkolnym. W: Paradygmaty współczesnej kultury fizycznej i zdrowotnej. (red.). Kaźmierczak A, Maszorek - Szymala A, Kowalska J. Wydawnictwo UŁ;2011. 109 - 117.

${ }^{12}$ Makarczuk A. Rodzice wobec problemu wad postawy ciała dzieci w wieku przedszkolnym. W: Praktyczny i teoretyczny wymiar aktywności fizycznej i sportu dla wszystkich. (red).. Nowocień J, Zuchora K, Fundacja Centrum Edukacji Olimpijskiej. AWF Warszawa; 2015. 353 - 362. Polish.

${ }^{13}$ Makarczuk A, Głuchowski R. Rodzice wobec problemu aktywności ruchowej i korekcji postawy ciała dzieci w wieku wczesnoszkolnym. W: Aktywność ruchowa osób w różnym wieku. (red.). Umiastowska D. 2017; (36): $19-28$. Polish.
} 
daily basis. Hence, the role of parents has always been extremely significant in this matter. Proper organization of the day, the right amount of outdoor activities, sleep, proper nutrition and help in performing a daily portion of compensatory and corrective exercises - these are the elements of the 24-hour impact on the child's body that parents and guardians must take care of ${ }^{14}$.

Summing up the above considerations, it should be stated that work to educate and activate parents to take actions to prevent posture defects, so often recommended in recent years, is still needed. The more so as the period of the COVID-19 pandemic and its numerous limitations, especially remote learning, certainly did not have a positive effect on the body posture of children and adolescents.

\section{Literature}

1. Kasperczyk T. Wady postawy ciała. Wyd. Kasper. Kraków; 1996. 5 - 7. Polish.

2. Kochman D, Studzińska A. Analiza częstości występowania oraz czynników wpływających na powstanie wad postawy u dzieci w wieku szkolnym. W: Innowacje w pielęgniarstwie i nauka o żywieniu. 2020; 3(5). 69 - 95.

3. Kutzner - Kozińska M. Proces korygowania wad postawy. Wyd. AWF Warszawa; 2001. 32. Polish.

4. Maciałczyk - Paprocka K. Epidemiologia wad postawy u dzieci i młodzieży. UM w Poznaniu; 2013. praca doktorska, www.wbc.poznan.pl; 43, 88 - 89. Polish.

5. Makarczuk A. Świadomość rodziców w zakresie występowania wad postawy ciała wśród dzieci w wieku przedszkolnym. W: Paradygmaty współczesnej kultury fizycznej i zdrowotnej. (red.). Kaźmierczak A, Maszorek - Szymala A, Kowalska J. Wydawnictwo UŁ;2011. 109 - 117.

6. Makarczuk A. Rodzice wobec problemu wad postawy ciała dzieci w wieku przedszkolnym. W: Praktyczny i teoretyczny wymiar aktywności fizycznej i sportu dla wszystkich. (red).. Nowocień J, Zuchora K, Fundacja Centrum Edukacji Olimpijskiej. AWF Warszawa; 2015. 353 - 362.

7. Makarczuk A, Głuchowski R. Rodzice wobec problemu aktywności ruchowej i korekcji postawy ciała dzieci w wieku wczesnoszkolnym. W: Aktywność ruchowa osób w różnym wieku. (red.). Umiastowska D. 2017; (36): 19 - 28.

8. Sitek M. Wady postawy dzieci - stan wiedzy rodziców. Wychowanie Fizyczne i Zdrowotne. 2014; 5: $14-17$.

\section{Internet sources}

9. https://www.nik.gov.pl/aktualnosci/profilaktyka-wad-postawy.html (dostęp: 11.01.22r)

\footnotetext{
${ }^{14}$ Kutzner - Kozińska M. Proces korygowania wad postawy. Wyd. AWF Warszawa. 2001. 83. Polish.
} 